\title{
The integrity and collaborative mode and path innovation research of College students' ideological and political education
}

\author{
Xiaofei Wang ${ }^{1}$, Jiawang Kuang ${ }^{1, *}$ \\ ${ }^{1}$ Hainan Medical University, Haikou, Hainan Province, China \\ *Corresponding author
}

Keywords: College students, ideological and political education, integrated, collaborative, mode and path, innovation

\begin{abstract}
To solve the problems facing the current ideological and political education, colleges and universities must improve the recognition of the importance of ideological and political education work, the ideological and political education by building integrity and collaborative operation mechanism and establish and improve ideological and political education innovation network, the establishment of a comprehensive mechanism of ideological and political education innovation, the formation of the ideological and political education are resultant force.
\end{abstract}

\section{Introduction}

With the development of economic globalization and the deepening of the socialist market economic construction, complex domestic and international situation changes on college students' ideological and political education work puts forward higher requirements. The popularization of higher education will bring the number of college students' growing and quality is uneven, and also to the traditional model of ideological and political education has brought serious challenges [1]. At present, the ideological and political education should be combed through positive there are all kinds of problems, improve the understanding of ideological and political education, to establish a comprehensive and systematic ideological and political education system, and build effective mechanism of ideological and political education, to improve the quality of ideological and political education.

\section{The problems existing in the college students' ideological and political education work}

"How to train the talent", what talent cultivation is the chief problem of higher education to solve, also is the important task of ideological and political education. The party central committee and the state council on further strengthening and improving ideological and political education of college students opinions explicitly put forward: "the school education should adhere to education, moral education first, talents cultivation as the fundamental task, the ideological and political education in the first place. "Insufficient attention of ideological and political education work is still the root cause of the current problems [1]. Because not value, so there exist deviations in understanding of ideological and political education work. Because they do not seriously, ideological and political work in colleges and universities play a proper role, a lot of time in "is important, to do the secondary, busy don't". The resulting of the construction of the ideological and political education mechanism is insufficient, mainly reflected in the following respects.

First, the leadership mechanism is not sound. Ideological and political education work is a lack of overall planning and unified guidance, lack of coordination between different departments.

Second, the ideological and political course system construction, existing curriculum courses in not enough, and time needed and students the truth out of line, backward education teaching methods, etc. 
Third, the ideological and political education is discipline. The ideological and political education from the professional education, the lack of mutual penetration, should is difficult to implement.

Fourth, the ideological and political education is administrative separation. Administrative system is not fully give play to the role of ideological and political education, education teaching departments disconnect, belong to different head, lack of communication and coordination mechanism, working hard to implement; Grasp and assessment of the student thought political education condition often is limited in the thought political lesson classroom assessment [2].

Fifth, the ideological and political education worker team is not perfect, is not stable. Ideological and political work content is widespread, workload is big, big political responsibility. But due to a lack of attention, the reality is often a lack of or personnel are of variable quality. If the lack of incentive is mechanism, weakening the ideological and political workers will lead to ideological and political workers underpowered and unstable.

Sixth, the lack of investment, ideological and political work is the spiritual world of work for a long time, need to human, material and energy in many aspects, but because of its cycle is long, difficult to quantify, performance measures, such as reason, lead too many colleges and universities are lack.

\section{The ideological and political education innovation system construction ideas together}

Ideological and political work is the lifeline of all work, with the characteristics of all-round, multi-angle, inevitably penetrated into every aspect, and can't count on leadership and administrative personnel of full-time work. We must manage concertedly; form the resultant force [2]. In the face of various problems existing in the process of ideological and political education, should grasp the integrity of ideological and political education, ideological and political education by building collaborative innovation mechanism in order to break through the dilemma.

First, we must realize the importance of ideological and political education. The deviation of the understanding of ideological and political education work lies in not straightens out the ideological and political education and school of professional education, intellectual education the relationship between. Moral education and intellectual education of colleges and universities is the inner unified relationship. Moral education not only refers to the political education, there are more rich ideological education category; Intellectual education is responsible for imparting professional knowledge, but also teach the main way of moral education [2]. Moral education should permeate all the school education, teaching activities, therefore, should be established with the ideological and political education as the core and outstanding professional education system of education.

Second, must recognize that to carry out the ideological and political work is the key to improve the leading system. System effective ideological and political work requires uniform standard, unified thought, unified pace; cooperate with each other [2]. Only under the perfect leadership system, can break the old situation of regional segmentation, manages concertedly, forming resultant force; To pass the effective implementation of the system, give full play to the initiative of all departments, let all departments actively cooperate with, each manager, construct the mechanism of cooperative innovation with ideological and political education.

Third, we must build perfect the ideological and political education of cooperative innovation mechanism. "Collaborative innovation" strong consolidation of the whole school ideological and political education effective use of various resources, through the perfect organizational structure and management system of the ideological and political work, to realize the school the largest force of ideological and political education, to promote the development of ideological and political education work.

\section{The innovation of the ideological and political education as a whole and build synergy mechanism}

Ideological and political education according to the above ideas, build perfect synergy innovation mechanism should do a good job of two levels: one is closely linked to the construction of resources, 
unified goal, work linkage, inside and outside the orderly coordinated operation mechanism, ensure the integrity of the implementation of ideological and political education work and orderly; Second, sweeping reform of ideological and political education, innovation education content, teaching evaluation methods, network education, etc. , give full play to the whole school ideological and political education innovation strength, to establish the three-dimensional network of ideological and political education to form a powerful education resultant force [3].

Play a role of value orientation, and to ensure that the ideological and political education goals. To ensure that the goals of ideological and political education as a whole must give full play to the socialist core value system in college students' ideological and political education value orientation of the overall synergy effect [3]. This is due to the fact that the socialist core value system as the spirit of the Chinese flag, is leading the spiritual kernel of the development of ideological and political education, enrich the content of ideological and political education system framework, in put forward higher requirements for ideological and political education at the same time, also for the ideological and political education in colleges and universities to establish the goals and direction. Therefore, exploring the ideological and political education as a whole, the mechanism of synergy of socialist core value system must be in harmony the whole process of students' ideological and political education of National People's Congress, made of various elements of the ideological and political education, and each link can be in accordance with the requirements of the socialist core value system organically together, in order to promote college students' all-round development as the goal, constantly improve the ideological and political education of integrity, collaborative, and gradually form and improve the ideological and political education the overall coordination of long-term mechanism.

Improve the efficiency of resource allocation, the depth of the integration of ideological and political education resources. The integration depth of ideological and political education resources are not simple addition of resources, but with different sources, different structure, different content, different levels resource selection and configuration, activation and integration [3]. At present, in the process of ideological and political education the overall coordination, the depth of the ideological and political education resources integration, there are still many problems to be solved. For example, in the ideological and political education as a whole still exist in the process of collaborative information asymmetry, the organization not harmonious, policies are not synchronized, project imbalance problem. These problems for long-term effective mechanism for the ideological and political education the overall synergy generated will be direct or indirect impact. Deep integration of ideological and political education resources, therefore, must improve the ideological and political education resources allocation efficiency. A need to improve information resources allocation efficiency, solve the college students' ideological and political education information asymmetry problems in the overall coordination.

Secondly, to improve the efficiency of the organization's resource allocation, solve the college students' ideological and political education in the overall coordination organization coordination problems.

Third, we need to improve the resource allocation efficiency of policy, solve the college students' ideological and political education in the overall coordination policy sync problem.

Fourth, we need to improve the resource allocation efficiency of the project, solve the college students' ideological and political education in the overall coordination project imbalance problem.

Strengthen grass-roots organization ability, form the college students' ideological and political education resultant force as a whole. Exploring the ideological and political education as a whole, the mechanism of synergy must be trying to form a family, school, social common concern, concern, participation, support the whole of the ideological and political education resultant force on work. In the process, schools need to mobilization, organization, coordination of key role. It is objectively need to constantly enhance the capacity of college grassroots organizations [4]. Colleges' basic level party organizations for a long time, and youth league organizations, as well as hospital, department of labor department of family, school, society organization are linked together by bridge and the link, is organic fit, family, school, society and the key points. Exploring the ideological and 
political education as a whole, the mechanism of synergy is form the integrated force of the ideological and political education, the need to strengthen the basic-level organization ability three aspects [4]. One is to strengthen grass-roots organization itself in college ideological and political education in the overall coordination organization and mobilization ability;2 it is to specific ideological and political education activities and projects, strengthen basic level, social organization and family communication and coordination ability; Three is to strengthen the ideological and political education of college grassroots organizations overall coordination of the allocation of resources ability, from the aspect of college grassroots organizations to improve college students' ideological and political education resources allocation efficiency.

Informational coordination. Goal conflict is a one-way demand informational coordination relation of a pair of basic. In this kind of collaborative form, although the cooperative parties target is not completely consistent, resources interdependent degree is low, but, as long as there is the need of overall coordination, one party through effective communication, can produce synergies as a whole. Therefore, information, especially the effective information is that the synergy of critical resources.

In the process of ideological and political education, the more typical cooperation mainly reflects in the informational school through various channels, accurate and timely message ideological and political education to the world and strives to college students' all-round development, as well as the ideological and political education to build a good environment [5]. These release information about my job trends, policies and regulations, employment, entrepreneurship, grants, loans and so on all aspects of the ideological and political education, to make family, society to know more about, pay attention to the ideological and political education work, and participate in the ideological and political education, the formation of family, school, society as a whole, coordination of the resultant force.

A dialogue together. Goals a one-way demand is interactivity together a pair of basic relations. In the form of this kind of collaborative and cooperative parties although goal is consistent, but as a result of mutual resources dependence is not high, before did not form the overall synergy long-term mechanism, through dialogue to need to continue to integrate resources, to achieve the common goal. Therefore, effective communication and dialogue is the key to this synergy produced.

In the process of ideological and political education, the more typical conversational synergy is mainly manifested in the educational work of university practice, especially in education to establish a relatively stable practice base [5]. As is known to all, practice education base is to carry out the practice education work important carrier. Education ought to say, to establish a relatively stable practice base is a systematic project, not only need to support regional departments, universities and colleges in need more efforts to strengthen the communication with the enterprises and institutions, dialogue and consultation.

Operational synergy, goal conflict, a two-way demand are operational synergy of a pair of basic relations. In this kind of collaborative form, cooperative parties target is not completely consistent, but in some specific activity, to better achieve their activities, cooperative parties to each other have resource has the objective need, thereby doing activities related equipment and operational cooperation [6].

In the process of ideological and political education, the more typical operational synergy is mainly embodied in, enterprises and institutions in the form of support sponsorship, held together with the universities, such as sports, liberal arts, nature, diathesis developing college students' ideological and political education activities. It should be pointed out that, in the process of the activities of the host, the relationship between universities and enterprises and institutions, is not only a kind of be sponsor and sponsor relationship, but also a kind of equipment for specific activity relations of cooperation.

Value together. Goals are two-way demand collaborative value of a pair of basic relationships. In this kind of collaborative relationship, collaborative parties not only consistent aim, and the degree of resource dependence between each other is also high. Because the goals and helping the parties will be able to target oriented, the target value orientation through the overall coordination of the various elements, each link [6]. At the same time, because of complementary resources, cooperative parties 
can form relatively stable, sustainable, standardized and institutionalized collaborative relationship as a whole.

Was typical in the process of ideological and political education, the value of the synergy is mainly manifested in the ideological and political education "main channel" and "position" overall coordination. Through "main channel" is the theory of ideological and political education, ideological and political theory course teaching. In the new era of ideological and political theory course update education teaching idea, strengthen the construction of teaching material and curriculum system research, perfecting teaching method and mode, the implementation of ideological and political theory Ding Cheng fine course construction, strengthening the course attraction and appeal of college students. "Position" is the daily ideological and political education, through the counselor on college students' daily education and management to achieve [3]. Ideological and political education of college students' daily in the new period to strengthen in the improvement, development in innovation, constantly explore the network ideological and political education, mental health education, etc, has achieved fruitful results.

\section{Summary}

College students' ideological and political education cooperative innovation mechanism construction is a complicated and systematic, long-term work, we must constantly research, reform and innovation, from the build effective running mechanism and constantly improve the ideological and political education two aspects promote all aspects of the work to build a wide range of staff participation, high permeability, strong pertinence, weight method to guide the ideological and political activity model of collaborative innovation of ideological and political system, how to improve college students' ideological and political education actual effect, for the socialist construction of qualified personnel training to adapt to the era development.

\section{References}

[1]Sh.H. Liu, Ideological and political education resultant force, Guangzhou: Sun Yat-Sen University, 2009, vol. 7, pp. 10-14.

[2] Ch. L. Ma, Discuss about the dialectical relationship of university moral education and intellectual education, Mudanjiang medical school journal, 2005, vol. 2, pp. 23-26.

[3] J.M. Jiang and H.B. Wang, The political education of college student's education of collaborative innovation research, Journal of Tonghua normal university, 2013, vol. 5, pp. 61-63.

[4] G.T. Feng, Ideological and political education innovation and development, Beijing: China Renmin University press, 2009, vol. 1, pp. 31-35.

[5] Z.Y. Yang, W.Ch. Li, Examination mode and its reform of ideological and political theory, Proceedings of the national education administration college, 2007, vol. 2, pp. 44-46.

[6] X.J. Wang and G.T. Chao, Ideological and political education, holistic collaborative innovation, Hubei academy of social sciences, 2016, vol. 12, pp. 71-76. 